\title{
Stomatal Conductance of Cowpea Submitted to Different Hydric Regimes in Castanhal, Pará, Brazil
}

Deborah Luciany Pires Costa (Corresponding Author), Amanda Yoko Takaki, Vivian Dielly da Silva Farias, Erika de Oliveira Teixeira, Hildo Giuseppe Garcia Caldas Nunes, Paulo Jorge de Oliveira Ponte de Souza

Universidade Federal Rural da Amazônia (UFRA), Belém, PA, Brazil

E-mail: deborahpires.agro@gmail.com

Received: Oct. 16, 2019

doi:10.5296/jas.v8i2.15628
Accepted: Nov. 20, 2019 Published: Dec. 23, 2019

URL: https://doi.org/10.5296/jas.v8i2.15628

\begin{abstract}
Cowpea is a culture of great socioeconomic relevance for northern Brazil, but the knowledge about technology that increases productivity, such as irrigation, is still incipient. The objective of this work was to evaluate the stomatal conductance $\left(\mathrm{g}_{\mathrm{s}}\right)$ of cowpea, in different hydric availabilities, Castanhal-PA. For this, it was planted the cv. BR3 Tracuauteua was planted in 0.5 ha in the year 2013, in the center of this area was instrummented a micrometeorological tower for measurements of atmospheric variables. The experimental design was in randomized blocks with 4 treatments, which were: $0 \%, 25 \%, 50 \%$ and $100 \%$ of the water slide as a function of crop evapotranspiration. The treatments started in the reproductive phase. The $g s$ readings were performed at different phenological stages through a porometer, the data were subjected to analysis of variance (Tukey, $\mathrm{p}<0.05$ ). In the reproductive phase, the lowest gs values were found in the $0 \% 0 \%$ of ETc, which were 141.08 and $186.80 \mathrm{mmol} \mathrm{m}^{-2} \mathrm{~s}^{-1}$, respectively, in the R7 and R8 stages. In contrast, the highest values were observed in T100\%, $777.76 \mathrm{mmol} \mathrm{m}^{-2} \mathrm{~s}^{-1}(\mathrm{R} 7)$ and $754.50 \mathrm{mmol} \mathrm{m}^{-2} \mathrm{~s}^{-1}$. The ideal water depth for cowpea stage R7 was $25 \%$ of ETc, whereas from R8, the ideal water depth was $50 \%$ of crop evapotranspiration.
\end{abstract}

Keywords: irrigation, meteorological variables, Vigna unguiculata (L.) walp

\section{Introduction}

Cowpea (Vigna unguiculata (L.) Walp) also known as string beans. It is a crop that has good adaptability to various environmental conditions, characteristics which promoted its high acceptability of cultivation (Silva et al., 2017). This legume has a high nutritional value, being an excellent source of protein, carbohydrates, vitamins and minerals, besides having a large amount of dietary fibers (Coffigniez et al., 2018).

This grain is the second most consumed type of bean in Brazil, and its cultivation is 
concentrated in the North, Northeast and in recent years has grown in the Midwest. Despite relevance, in Brazil there are no official statistics on cowpea production, therefore, existing information is estimated CONAB (2017), in which the largest national producers are the states of Mato Grosso, Ceará and Maranhão (Rocha et al., 2017).

The northeastern Paraense mesoregion, which is located in the municipality of Castanhal, assumed in 2008 a representative scenario in cowpea production; however, with the advance of other agricultural activities, production decreased, in this context, other more technically-oriented regions, such as Midwest region, expanded grain production, since among the precision technologies used by producers in this region is irrigation (Souza et al., 2017).

Another important factor that contributed to the decrease in cowpea productivity was climate variations, such as the occurrence of La Niña, where it is an extreme scalable event that is specified by the Pacific's abnormal cooling of water, or what implications for the Amazonian glove regime (Islam \& Gan, 2015). This event occurred in 2009, unlike other factors that influence production, such as nutrition, there is no control over the meteorological variables so, a The solution is to adapt and search for means that ensure viable production under adverse weather conditions, such as checking the best window for planting and applying irrigation systems (Souza et al., 2019).

In ecophysiological terms, the main variables that indicate whether a particular plant has metabolic difficulties in detriment of environmental conditions are stomatal conductance, transpiration and photosynthetic rate, often used as indicators, as they are involved in the metabolic activities of plants that result in the formation of biomass, and consequently in production (Verbree et al., 2014).

The stomatal conductance is the process of stomata movement, which allows the passage of water in the form of steam from the plant to the atmosphere due to a pressure gradient, ie, perspiration (Taiz \& Zeiger, 2017). In general, climate variables such as incident global radiation, precipitation, temperature, relative humidity, water vapor pressure deficit and wind speed directly impact productivity as they influence gas exchange and plant water status (Silva et al., 2017).

The use of irrigation systems has been an alternative to regulate the water state of the plants, enabling the production in dry season. In this way, irrigation becomes an efficient way to ensure that the plant maintains a good water status during its cycle, preventing the vegetation from suffering water stress and, in turn, achieving quality production, in contrast to this. The need for sustainable use of natural resources (Morgado et al., 2017).

Stomatic conductance is a physiological indicator of water status, thus it is used to define the appropriate water depth limits for the plant (Ahumada-Orellana et al., 2019). Given this context, to properly define irrigation technology for cowpea crop, the objective of this study was to evaluate the stomatal conductance of the present crop submitted to different irrigation depths in its reproductive phase in the municipality of Castanhal-PA. 


\section{Material and Method}

\subsection{Experimental Area}

The experiment was carried out at the Experimental Farm of Castanhal, belonging to the Federal Rural University of Amazonia, in the municipality of Castanhal, northeast Paraense $\left(01^{\circ} 17^{\prime}\right.$ 'S and $\left.47^{\circ} 55^{\prime} \mathrm{W}\right)$. According to the Köppen classification, the predominant climate type in the region is tropical humid (Am) with the presence of a small dry season, with an average annual temperature of $26^{\circ} \mathrm{C}$ with a maximum and minimum of 35 and $20^{\circ} \mathrm{C}$, respectively. The average relative humidity is $80 \%$ and the average annual precipitation between 2000 and 2,500 mm (Alvares et al., 2013).

The experiment took place between October and December 2013, the region's drought. An area of 0.5 ha in which cowpea cv. BR3 Tracuateua planted on October 1, 2013. The soil was prepared conventionally (one plow and three harrows), with mechanized sowing, adopting a spacing of $0.5 \mathrm{~m}$ between rows with approximately 10 plants per linear meter., constituting a density of 200,000 plants per hectare.

The soil was classified as a dystrophic yellow latosol with a sandy texture based on the analysis carried out at Embrapa / Eastern Amazon with soil data collected in the experiment (Table 1).

Table 1. Chemical and mineralogical analysis of soil (depth $0-20 \mathrm{~cm}$ ) of the experimental area in Castanhal-PA

\begin{tabular}{c|c|c|c|c|c|c|c|c|c|c|c|c|c}
\hline $\mathrm{pH}$ & $\mathrm{N}$ & $\mathrm{MO}$ & $\mathrm{P}$ & $\mathrm{K}$ & $\mathrm{Na}$ & $\mathrm{Ca}$ & $\mathrm{Ca}+\mathrm{Mg}$ & $\mathrm{Al}$ & $\mathrm{H}+\mathrm{Al}$ & $\begin{array}{c}\text { Coarse } \\
\text { sand }\end{array}$ & $\begin{array}{c}\text { Thin } \\
\text { sand }\end{array}$ & Silt & Clay \\
\hline Water & $\%$ & $\mathrm{~g} / \mathrm{kg}$ & \multicolumn{2}{|c|}{$\mathrm{mg} / \mathrm{dm}^{3}$} & \multicolumn{3}{|c|}{$\mathrm{cmol}_{\mathrm{c}} / \mathrm{dm}^{3}$} & \multicolumn{5}{|c}{$\mathrm{g} / \mathrm{kg}$} \\
\hline 5,1 & 0,06 & 16,88 & 71 & 35 & 3 & 3,2 & 4,4 & 0,1 & 1,98 & 322 & 450 & 129 & 100 \\
\hline
\end{tabular}

\subsection{Micrometeorological Variables}

In the center of the experimental area a $3.0 \mathrm{~m}$ high micrometeorological tower was installed, which housed an automatic weather station, with sensors for measuring incident global solar radiation $(\mathrm{Rg})$, air temperature $(\mathrm{T})$ and relative humidity $(\mathrm{RH})$, rainfall and soil water moisture content $(\theta)$. These sensors were connected to a datalogger (CR10X, Campbell Scientific) and a multiplexer (AM416, Campbell Scientific), which performed readings every 10 seconds and recorded averages and totals every 10 minutes.

The vapor pressure deficit (DPV) was calculated by the difference in saturation pressure and actual water vapor pressure obtained from air temperature and relative humidity data, according to the Tetens (1930) methodology.

\subsection{Experimental Design and Applied Treatments}

A randomized block experimental design was adopted, whose experimental units consisted of 
6 blocks measuring 24 × $22 \mathrm{~m}$, separated by a $1.0 \mathrm{~m}$ border, where each block contained 4 treatments, corresponding to $0 \%, 25 \%, 50 \%$ and $100 \%$ of the daily irrigation water depth required for cowpea crop, calculated through crop evapotranspiration.

Irrigation was applied homogeneously throughout the area during the vegetative phase with a drip irrigation system to ensure the establishment of the crop. The treatments were distinguished during the reproductive stage. These were, T0\% (rainfed), T25\%, T50\% and T100\%. The percentage was a function of daily culture evapotranspiration (ETc). The ETc was estimated by equation 1 .

$$
E T c=E T o^{*} K c
$$

ETc - crop evapotranspiration $\left(\mathrm{mm} \mathrm{d}^{-1}\right)$;

ET0 - reference evapotranspiration $\left(\left(\mathrm{mm} \mathrm{d}^{-1}\right)\right.$;

Kc - crop coefficient.

Daily ET0, obtained by the Penman-Monteith method (Allen et al., 2011) was determined, with data measured at an INMET weather station installed in Castanhal-PA, and Kc according to results from Bastos et al. (2008).

The phenological monitoring was performed according to the scale proposed by Gepts and Fernández, described by (Farias et al., 2017). In which the beginning of the phenological phase was defined when $50 \%+1$ of the plants reached the stage in question. For this, evaluation was stipulated in each plot 1 linear meter, with 10 plants, for daily observation. The steps were identified as follows: V0 (germination); V1 (above ground cotyledons); V2 (expanded cotyledon leaves) V3 (1st open trifoliate leaf); V4 (3rd open trifoliate leaf); R5 (1st flower bud); R6 (1st flower anthesis); R7 (release of the pods); R8 (grain filling); R9 (physiological maturity).

\subsection{Stomach Conductance Monitoring}

The stomatal conductance of the crop was monitored using a Type AP4 steady state porometer (Delta-T Devices), starting as collections at $8 \mathrm{~h}$ and ending at $16 \mathrm{~h}$, in leaves located at the top of the plant. The readings were performed on the unshaded central mature leaflets. Readings were taken on 48 plants per hour.

Four evaluation days were selected, which represented two days were performed in the vegetative phase (at stage V4) at 28 days after sowing (DAS), and two days were made in the reproduction phase, at stages R7 (41 DAS) and R8 ( 47 DAS).

\subsection{Statistical Analysis}

Statistical analysis of the data obtained concerning meteorological variables, incident global radiation $(\mathrm{Rg})$, temperature $(\mathrm{T})$, relative humidity $(\mathrm{RH})$, vapor pressure deficit (DPV) and eventual precipitation (PP), and stomatal conductance $\left(\mathrm{g}_{\mathrm{s}}\right)$. Were analyzed descriptively through means and standard deviations. The mean values of $g s$ were subjected to analysis of variance and the means compared by Tukey test at $5 \%$ probability. 


\section{1) Macrothink}

\section{Results and Discussion}

The variability of the weather conditions during the crop cycle were: Average $\operatorname{Rg}$ was 16.34 $( \pm 2.90) \mathrm{MJ} \mathrm{m}^{-2} \mathrm{~d}^{-1}$, with a variation between 7.346 and $21.29 \mathrm{MJ} \mathrm{m}^{-2} \mathrm{~d}^{-1}$, and the average air temperature was $26.72( \pm 0.73)^{\circ} \mathrm{C}$, with a minimum of $24.28^{\circ} \mathrm{C}$ and a maximum of $28.10^{\circ}$ C. Evapotranspiration of the average culture was $3.26( \pm 0.87) \mathrm{mm} \mathrm{d}^{-1}$, with accumulated $218.58 \mathrm{~mm}$ (Figure 1).

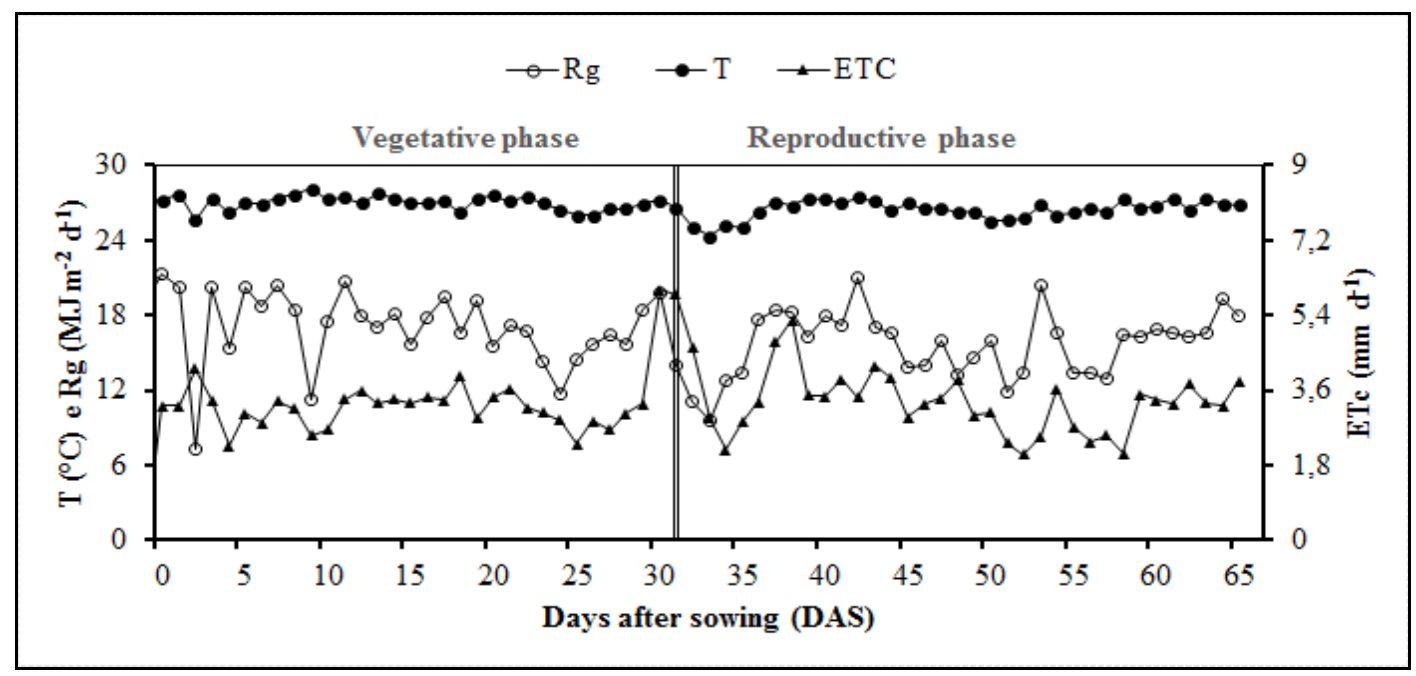

Figure 1. Incident global radiation ( $\mathrm{Rg}$ ), air temperature $(\mathrm{T})$ e crop evapotranspiration (ETc) during the cowpea cycle, Castanhal-PA

The total rainfall during the experiment was $280.40 \mathrm{~mm}$, where it was concentrated during the reproductive phase of the crop, presenting a higher occurrence of $65.53 \mathrm{~mm}$ in 56 DAS. The values of $\theta$ did not show differentiation during the vegetative phase, since in this period the treatments had not yet been arranged. In this period $\theta$ was $0.17 \mathrm{~m}^{3} \mathrm{~m}^{-3}$. In the reproductive phase, mean values were $0.16( \pm 0.04), 0.17( \pm 0.04), 0.18( \pm 0.04)$ and $0.20( \pm 0.03) \mathrm{m}^{3} \mathrm{~m}^{-3}$, for the treatments $0 \%, 25 \%, 50 \%$ and $100 \%$, respectively (Figure 2). Soil water moisture variability is constantly influenced by rainfall and irrigation depths, as observed in the value of each treatment. 


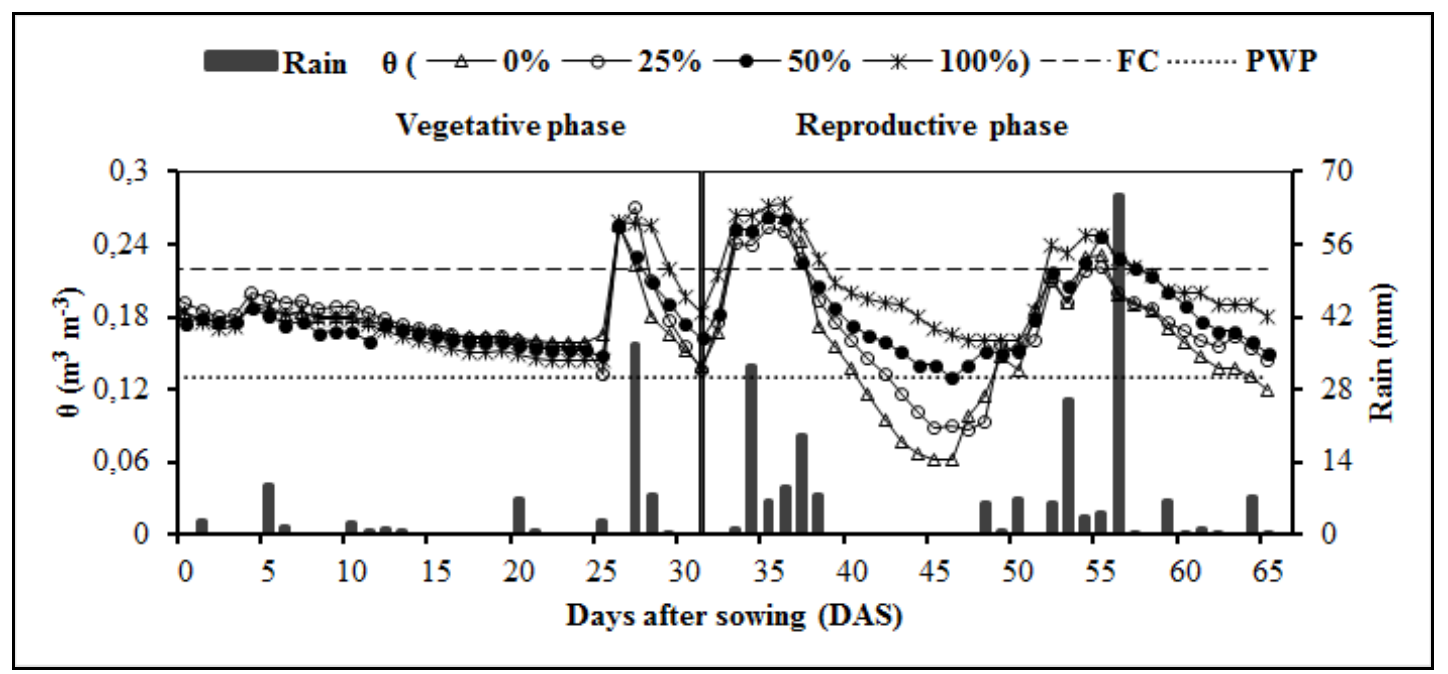

Figure 2. Rain and soil water contente $(\theta)$ in treatments $0 \%, 25 \%, 50 \%$ e $100 \%$. FC $-\theta$ in field capacity; PWP- $\theta$ in permanent withering point

On day 21 DAS, which corresponded to the phenological stage V4, the average $\mathrm{Rg}$ was 568.59 ( \pm 263.22$) \mathrm{W} \mathrm{m}^{-2}$, ranging from 129.17 to $815.62 \mathrm{~W} \mathrm{~m}^{2}$. The average $\mathrm{T}$ was 31.35 ( \pm 1.74) ${ }^{\circ} \mathrm{C}$, where the minimum was $29.48^{\circ} \mathrm{C}$ and $33.04^{\circ} \mathrm{C}$ (3a). At $28 \mathrm{DAS}, \operatorname{Rg}$ was 448.36 $( \pm 228.83) \mathrm{W} \mathrm{m}^{-2}$, with amplitude of $113.13 \mathrm{~W} \mathrm{~m}^{-2}$ and $726.47 \mathrm{~W} \mathrm{~m}^{-2}$, and $\mathrm{T}$ was $30.05( \pm$ 1.58) ${ }^{\circ} \mathrm{C}$, ranging from 27.21 to $32.10^{\circ} \mathrm{C}$ (Figure $3 \mathrm{~d}$ ). 

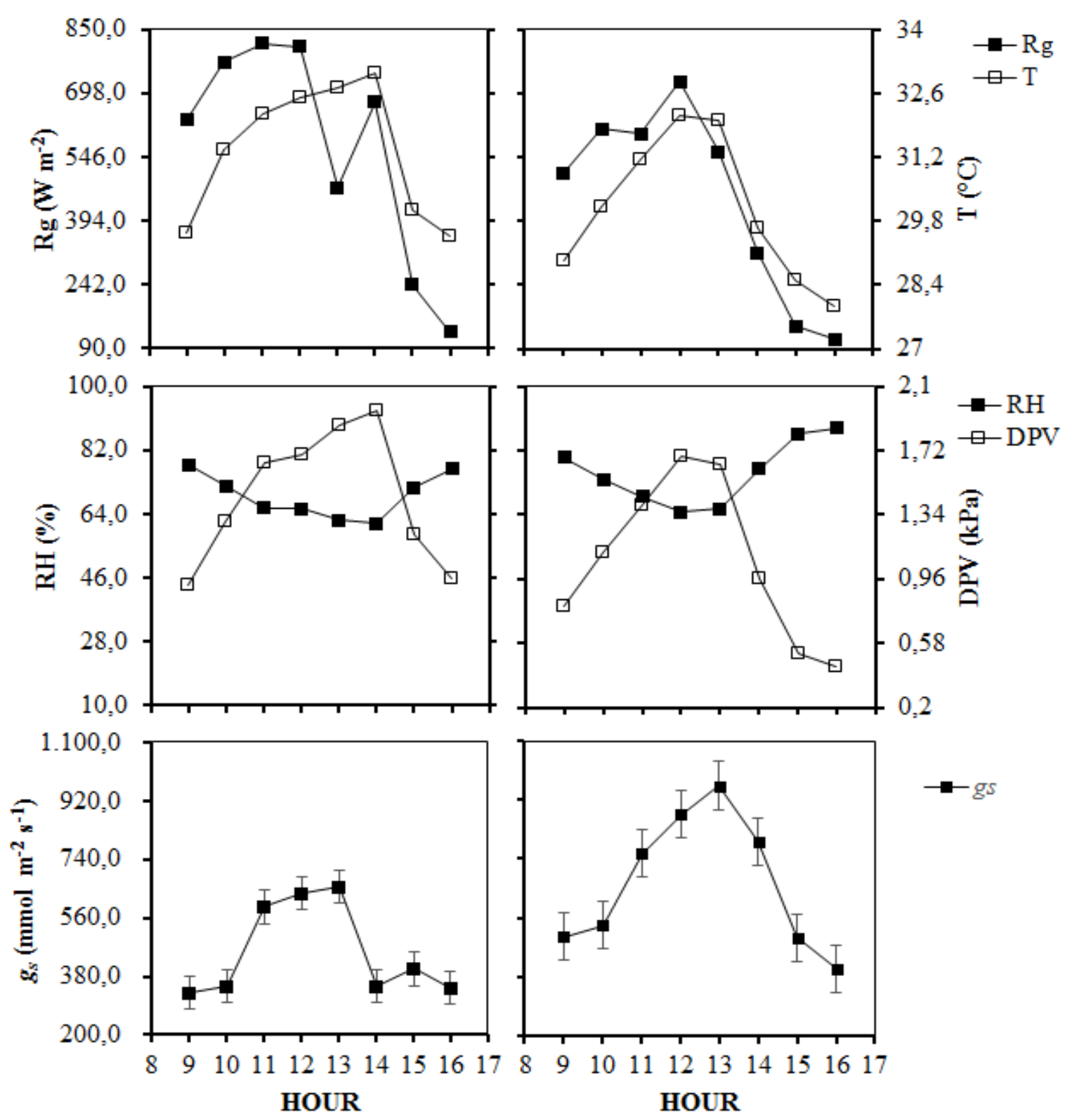

Figure 3. Meteorological variables and stomatal conductance in the cowpea vegetative period, where (a), (b) and (c) are 21 DAS values and, (d), (e) and (f) are at 28 DAS. Incident Global Radiation (Rg) and Air Temperature (T)-(a) and (d); Vapor pressure deficit (DPV) and Relative humidity (UR)-(b) and (e); hourly variability of $g s$ (stomatal conductance)-(c) and (f)

In the 21 DAS the RH was $69.04 \%$ ( \pm 6.36$)$, ranging from $61.17 \%$ to $77.88 \%$, and on day $28 \mathrm{DAS}$ it was $75.61 \%( \pm 8.96)$. DPV is a variable applicable to all other weather and climate conditions, so the first day averaged $1.44 \mathrm{kPa}( \pm 0.40)$, with a maximum of $1.96 \mathrm{kPa}$ and a minimum of $0.91 \mathrm{kPa}$. On the second day, mean DPV was $1.07( \pm 0.47)$, ranging from 0.44 to $1.68 \mathrm{kPa}$ (Figure $3 \mathrm{~b}$ and $3 \mathrm{e}$ ).

Under these conditions in the 21 and 28 DAS media, $496.71( \pm 146.40)$ and $666.29( \pm 205.90)$ mmol m $\mathrm{m}^{-2} \mathrm{~s}^{-1}$, respectively. The minimum values were 344.67 (21DAS) and $405.00 \mathrm{mmol} \mathrm{m} \mathrm{m}^{-2}$ $\mathrm{s}^{-1}$ (28 DAS). While the maximum values were 654.17 and $963,33 \mathrm{mmol} \mathrm{m}^{-2} \mathrm{~s}^{-1}$, respectively 


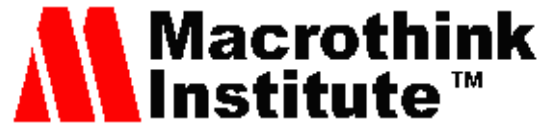

(Figure $3 \mathrm{c}$ and $3 \mathrm{f}$ ). At this phenological stage, as the plants were hydrated, that is, they were irrigated with $100 \%$ ETc, so all these responses and differences were affected in the functions of climate variation, not in the soil. Therefore, gs values in 28 DAS present higher values compared to $21 \mathrm{DAS}$, and this variation over the hours follows the variability of the meteorological conditions, mainly of the. As presentations of 21 DAS, what is the value of the smaller gs, possibly a defended plant recovers a stomatal problem with the use of avoiding water loss, as already observed in a study by Medina et al. (2017), who studied or limited DPV to interfere with bean plants.

Most studies conducted with the beginning of the reproductive phase, since although gs reach maximum values in the vegetative phase, it is in the reproductive phase that this variable has the highest sensitivity of the influence of water deficit (Nascimento et al., 2011). Therefore, the present study chose to differentiate the irrigation procedures from the first appearance of the flower bud.

Thus, the following assessments corresponded to the reproductive stages (Figure 4). In the R7 (41 DAS), the atmospheric conditions were similar to that of the anterior phase with a small increase in the evaporating power of the ar (DPV). The mean $\mathrm{Rg}$ was $17.90( \pm 2.14) \mathrm{MJ} \mathrm{m}^{-2}$ $\mathrm{d}^{-1}$, the average air temperature was around $30.79( \pm 1.33){ }^{\circ} \mathrm{C}$, the mean $\mathrm{RH}$ was $72.69( \pm$ $7.53) \%$ and the DPV was $1.23( \pm 0.39) \mathrm{kPa}$ (Figure 4). The daily average values of $g s$ for the treatments $0 \%, 25 \%, 50 \%$ and $100 \%$ of the daily ETc were $141.08 \mathrm{mmol} \mathrm{m}^{-2} \mathrm{~s}^{-1}( \pm 45,92)$, $698.01 \mathrm{mmol} \mathrm{m}^{-2} \mathrm{~s}^{-1}( \pm 109,62), 758.70 \mathrm{mmol} \mathrm{m} \mathrm{s}^{-1}( \pm 89.84)$ and $777.76 \mathrm{mmol} \mathrm{m}^{-2} \mathrm{~s}^{-1}( \pm$ 95.28), respectively (Figure $4 \mathrm{~A}, 4 \mathrm{~b}$ and $4 \mathrm{c}$ ).

In stage $\mathrm{R} 8$, there was a reduction in the incidence of solar radiation due to the increase of cloudiness generating an average $\mathrm{Rg}$ of $14.00( \pm 4.27) \mathrm{MJ} \mathrm{m}^{-2} \mathrm{~d}^{-1}$. Despite this detail, the other variables presented the same pattern observed in the previous days, with mean air $\mathrm{T}$ of $30.33( \pm 1.20){ }^{\circ} \mathrm{C}$, mean RH of $71.27( \pm 7.88) \%$ and DPV of $1.26( \pm 0.39) \mathrm{kPa}$ (Figure 4 of $4 \mathrm{e})$.

The average stomatal conductance on this day for the $25 \%, 50 \%$ and $100 \%$ treatments were $446.734 \mathrm{mmol} \mathrm{m}^{-2} \mathrm{~s}^{-1}( \pm 88.35), 629.854 \mathrm{mmol} \mathrm{m}^{-2} \mathrm{~s}^{-1}( \pm 116.58)$ and $754.505 \mathrm{mmol} \mathrm{m}^{-2} \mathrm{~s}^{-1}$ $( \pm 88.91)$, respectively (Figure $4 \mathrm{f})$, with similar variability, but with much more noticeable water restriction as a function of the 8 days imposition of treatment. The $0 \%$ treatment presented $g_{s}$ of $186.79 \mathrm{mmol} \mathrm{m}^{-2} \mathrm{~s}^{-1}( \pm 85.67)$, and showed completely inverse variability to the other treatments. Note that gas for the $25 \%$ treatment showed very different values from the $50 \%$ and $100 \%$ treatments, despite the same variability (Figure 4). 




Figure 4. Meteorological variables and stomatal conductance in the cowpea reproductive period, where (a), (b) and (c) are R7 values and, (d), (e) and (f) are R8. Incident Global Radiation (Rg) and Air Temperature (T) - (a) and (d); Vapor pressure deficit (DPV) and Relative humidity (UR) - (b) and (e); hourly variability of $g s$ (stomatal conductance) in the different irrigation treatments - (c) and (f)

The characteristics of $g s$ observed in treatments $0 \%$ and $25 \%$ are consequences of insufficient water supply for the normal maintenance of functionality of the stomatal conductance process, which may have affected other physiological processes, such as sweating and, mainly, photosynthesis, causing lower accumulation of dry matter (Medina et al., 2017).

Paiva et al. (2005), made a study similar to this study, where it determined values of $g_{s}$ of common bean plants at different phenological stages for different irrigation depths in the climatic conditions of Jaboticabal. The values of the reproductive stages varied according to the slides, which is similar to the present study, and also according to the climatic conditions, which were different in the days that the authors evaluated. Other studies with Cowpea performed in places other than this research showed that the variability of $g s$ was similar to the present study, with the main source of variation of stomatal conductance being the water slides (Oliveira et al., 2005).

Based on the statistical analysis, in R7, the treatments were not significant between the $25 \%$, 
$50 \%$ and $100 \%$ treatments, where only the $0 \%$ blade treatment was significantly different compared to all others. While in R8, the water slide treatments, $50 \%$ and $100 \%$, would not differ from each other, and these two presented differences and between $0 \%$ and $25 \%$, which were also different from each other (Table 2).

Table 2. Statistical analysis at stages R7 and R8 of $g s\left(\mathrm{mmol} \mathrm{m}^{-2} \mathrm{~s}^{-1}\right)$

\begin{tabular}{cccc|ccc}
\hline Treatment & \multicolumn{2}{c}{ R7 } & \multicolumn{2}{c}{$\mathrm{R} 8$} \\
\hline $0 \%$ & 141,08 & $\pm 45,92$ & $\mathrm{a}$ & 186,797 & $\pm 85,67$ & $\mathrm{a}$ \\
$25 \%$ & 698,01 & $\pm 109,62$ & $\mathrm{~b}$ & 446,734 & $\pm 88,35$ & $\mathrm{~b}$ \\
$50 \%$ & 758,70 & $\pm 98,04$ & $\mathrm{~b}$ & 629,854 & $\pm 116,58$ & $\mathrm{c}$ \\
$100 \%$ & 777,76 & $\pm 95,28$ & $\mathrm{~b}$ & 754,505 & $\pm 88,91$ & $\mathrm{c}$ \\
\hline
\end{tabular}

${ }^{1}$ Means followed by the same letter do not differ statistically from each other. Tukey test was applied at 5\% probability level.

${ }^{2}$ Tiny Words Represent Treatments

Given the results, it is clear that stomatal conductance is sensitive as irrigation depths, especially in the reproductive phase of the plant. The stage R8 was more sensitive to the application of the treatments, it is characterized by the biomass filling of the grains, so it is at this stage that the photoassimilates translocation from the leaves to the pods, thus causing the onset of leaf senescence (Feng et al.,2016). When this occurs the gas try to become more sensitive to any environmental stress.

In practical terms, when considering the stomatal conductance parameter as an ideal blade indicator for cowpea cultivation, it should be assumed that for each phenological stage a differentiated blade should be used, which will imply a more sustainable use of water resources.

\section{Conclusion}

1. In the vegetative phase was observed the highest gs values, in which the plants were receiving $100 \%$ of water replacement, in this condition, the variation between the 21 st and 28th day DAS was controlled by the variability of the climatic elements.

2. In the reproductive phase, the stomatal conductance of cowpea differs between the different water availability applied in the four phenological stages evaluated. The $0 \%$ treatment, that is, under rainfed conditions, reflects water stress to the crop in all stages evaluated in this study, in contrast to the treatment with $100 \%$ of irrigation reflected in the highest gs values.

3. Considering $g s$ as an indicator, at the R7 phenological stage, the $25 \%$ of the crop 
evapotranspiration slide is indicated as it does not cause damage to the crop's $g s$, whereas from the R8 phase of this legume, the ideal water depth is $50 \%$ of the evapotranspiration of culture.

\section{References}

Ahumada-Orellana, L., Ortega-Farías, S., Poblete-Echeverría, C., \& Searles, P. S. (2019). Estimation of stomatal conductance and stem water potential threshold values for water stress in olive trees (cv. Arbequina). Irrigation Science, 37(4), 461-467. https://doi.org/10.1007/s00271-019-00623-9

Allen, R. G., Pereira, L. S., Howell, T. A., \& Jensen, M. E. (2011). Evapotranspiration information reporting: I. Factors governing measurement accuracy. Agricultural Water Management, 98(6), 899-920. https://doi.org/10.1016/j.agwat.2010.12.015

Alvares, C. A., Stape, J. L., Sentelhas, P. C., de Moraes Gonçalves, J. L., \& Sparovek, G. (2013). Köppen's climate classification map for Brazil. Meteorologische Zeitschrift, 22(6), 711-728. https://doi.org/10.1127/0941-2948/2013/0507

Bastos, E. A., Ferreira, V. M., Silva, C. R. da, \& Andrade Júnior, A. S. de. (2008). Evapotranspiração e coeficiente de cultivo do feijão-caupi no vale do gurguéia, piauí. Irriga, 13(2), 182-190. https://doi.org/10.15809/irriga.2008v13n2p182-190

Coffigniez, F., Briffaz, A., Mestres, C., Ricci, J., Alter, P., Durand, N., \& Bohuon, P. (2018). Kinetic study of enzymatic a-galactoside hydrolysis in cowpea seeds. Food Research International, 113, 443-451. https://doi.org/10.1016/j.foodres.2018.07.030

CONAB. Acompanhamento da safra brasileira de grãos, v.5, n.7, Safra 2017/18. Brasília, 2018. 139 p.

Farias, V. D. D. S., Lima, m. J. A. De, Nunes, H. G. G. C., Sousa, d. D. P., \& Souza, P. J. D. O. P. D. (2017). Water demand, crop coefficient and uncoupling factor of cowpea in the eastern amazon. Revista caatinga, 30(1), 190-200. https://doi.org/10.1590/1983-21252017v30n121rc

Feng, Z., Wang, L., Pleijel, H., Zhu, J., \& Kobayashi, K. (2016). Differential effects of ozone on photosynthesis of winter wheat among cultivars depend on antioxidative enzymes rather than stomatal conductance. Science of The Total Environment, 572, 404-411. https://doi.org/10.1016/j.scitotenv.2016.08.083

Islam, Z., \& Gan, T. Y. (2015). Potential combined hydrologic impacts of climate change and El Niño Southern Oscillation to South Saskatchewan River Basin. Journal of Hydrology, 523, 34-48. https://doi.org/10.1016/j.jhydrol.2015.01.043

Medina, V., Teran, J. C. B. B.-M. y., Gepts, P., \& Gilbert, M. E. (2017). Low stomatal sensitivity to vapor pressure deficit in irrigated common, lima and tepary beans. Field Crops Research, 206, 128-137. https://doi.org/10.1016/j.fcr.2017.02.010

Morgado, M. A. D., Bruckner, C. H., Rosado, L. D. S., \& Santos, C. E. M. dos. (2017). Growth dynamics and allometric relationships of Passiflora species rootstocks. Comunicata 
Scientiae, 8(1), 1. https://doi.org/10.14295/cs.v8i1.1336

Nascimento, S. P. do, Bastos, E. A., Araújo, E. C. E., Freire Filho, F. R., \& Silva, E. M. da. (2011). Tolerância ao déficit hídrico em genótipos de feijão-caupi. Revista Brasileira de $\begin{array}{lllr}\text { Engenharia Agrícola Ambiental, } & \text { 15(8), }\end{array}$ https://doi.org/10.1590/S1415-43662011000800013

Oliveira, A. D. de, Fernandes, E. J., \& Rodrigues, T. de J. D. (2005). Condutância estomática como indicador de estresse hídrico em feijão. Engenharia Agrícola, 25(1), 86-95. https://doi.org/10.1590/s0100-69162005000100010

Paiva, A. S., Fernandes, E. J., Rodrigues, T. J. D., \& Turco, J. E. P. (2005). Condutância estomática em folhas de feijoeiro submetido a diferentes regimes de irrigação. Engenharia Agrícola, 25(1), 161-169. https://doi.org/10.1590/S0100-69162005000100018

Rocha, M. de M., Damasceno-Silva, K. J., Menezes-Júnior, J. Â. N. de, Carvalho, H. W. L. de, Costa, A. F. da, Lima, J. M. P. de, ... Morais, O. M. (2017). Yield adaptability and stability of semi-erect cowpea genotypes in the Northeast region of Brazil by REML/BLUP. REVISTA CIÊNCIA AGRONÔMICA, 48(5), 862-871. https://doi.org/10.5935/1806-6690.20170102

Silva, W. C., Moura, J. G. de, Oliveira, A. B. de, Ferreira, L. E., \& Silva, T. M. da. (2017). Growth and gas exchange in cowpea plants under different managements and saline conditions. Revista ciência agronômica, 48(5), 756-764.

https://doi.org/10.5935/1806-6690.20170088

Souza, P. J. D. O. P. D., Farias, V. D. D. S., Lima, M. J. A. D., Ramos, T. F., \& Sousa, A. M. L. D. (2017). Cowpea leaf area, biomass production and productivity under different water regimes in Castanhal, Pará, Brazil. Revista Caatinga, 30(3), 748-759. https://doi.org/10.1590/1983-21252017v30n323rc

Souza, P. J. O. P., Ramos, T. F., Fiel, L. de C. S., Farias, V. D. da S., Sousa, D. de P., \& Nunes, H. G. G. C. (2019). Yield and water use efficiency of cowpea under water deficit. Revista Brasileira de Engenharia Agrícola e Ambiental, 23(2), 119-125.

https://doi.org/10.1590/1807-1929/agriambi.v23n2p119-125

Taiz, L., \& Zeiger, E. (2017). Fisiologia vegetal. In Artmed (Org.) (5ºd, p. 918). 918.

Tetens, O. (1930). Ubercinigemeterorologische Begriffe. Z. Geophys., 6, 297-309.

Verbree, D. A., Singh, B. B., \& Payne, W. A. (2014). Role of Gas Exchange, Leaf Water Status, and Carbohydrate Partitioning During the Early Vegetative Stage on Drought Tolerance in Cowpea. Crop Science, 54(2), 770. https://doi.org/10.2135/cropsci2013.07.0437

\section{Copyright Disclaimer}

Copyright for this article is retained by the author(s), with first publication rights granted to the journal.

This is an open-access article distributed under the terms and conditions of the Creative Commons Attribution license (http://creativecommons.org/licenses/by/4.0/). 